\title{
Isolation and identification of Lactobacillus bacteria found in the gastrointestinal tract of the dwarf honey bee, Apis florea Fabricius, 1973 (Hymenoptera: Apidae)
}

\author{
Shabnam PARICHEHREH ${ }^{1}$, Gholamhosein TAHMASBI ${ }^{2}$, Alimorad SARAFRAZI ${ }^{3}$, \\ Sohrab IMANI ${ }^{1}$, Naser TAJABADI ${ }^{2}$
}

\author{
${ }^{1}$ Department of Agricultural Entomology, Science and Research Branch, Islamic Azad University, Tehran, Iran \\ ${ }^{2}$ Department of Honeybee, Animal Science Research Institute of Iran, Agricultural Research, Education and Extension \\ Organization (AREEO), Karaj, Iran \\ ${ }^{3}$ Department of Insect Taxonomy Research, Institute of Plant Protection, Agricultural Research, Education and Extension \\ Organization (AREEO), Tehran, Iran
}

Received 12 April 2017 - Revised 13 January 2018 - Accepted 20 February 2018

\begin{abstract}
Recent research in bacteria-insect symbiosis has shown that lactic acid bacteria (LAB) establish symbiotic relationships with several Apis species. The current study was carried out to isolate and identify Lactobacillus bacteria housed in the gastrointestinal tract of the Asian dwarf honey bee (Apis florea), which is distributed in different regions of Iran. The current study was performed using $100 \mathrm{Gram}$-stained isolates, which were tested for catalase activity. Bacterial universal primers were used to amplify $16 \mathrm{~S}$ rDNA genes isolated from bacterial colonies. Sequencing was done for 16S rDNA genes isolated from 43 bacteria. The phylogenetic analyses demonstrated that Lactobacillus flora found in the gastrointestinal tract of A. florea encompassed eight different phenotypes classified as three different species: $L$. kunkeei, L. plantarum, and L. apis. According to the specific association between bacteria and A. florea, we classified the Apis populations into three zones. Furthermore, the association of $L$. plantarum with insects foraging in citrus orchards might be explained by differences in nectar and pollen components resulting in the growth of different species of bacteria.
\end{abstract}

\section{Apis florea / lactic acid bacteria / 16S rDNA / symbiosis / Iran}

\section{INTRODUCTION}

In the insect world, there is a close association between insects and the microorganisms living in their digestive tracts, specialized cells, or organs (Bourtzis and Miller 2003). It has been suggested that microbiota composition depends on highly coevolved symbiosis and commensalism, which are affected by factors such as nutrition, physiology, and immune function (Eckburg et al. 2005; Backhed et al. 2005). The insect gut has

Corresponding author: G. Tahmasbi, gh.hoseintahmasbi@gmail.com

Manuscipt editor: Yves Le Conte always been considered an organ with high microbiological diversity (Dillon and Dillon 2004) where pathogen growth is efficiently suppressed by its microbiota.

In humans, insects, and other animals, lactic acid bacteria (LAB), known as commensal species (Hammes and Hertel 2006), are considered an important bacterial group in food industries such as dairy production. Furthermore, other LAB strains are considered safe food-grade microorganisms or probiotics and are used in human nutrition and health-related practices (FAO/WHO 2002). LAB found in humans and other animals play an important role in protecting their hosts through producing antimicrobial metabolites and modulating immune responses (Servin 2004; Ventura et al. 
2009). LAB microbiota works in a synergistic manner (Forsgren et al. 2010). They are able to produce proteins, peptides, organic acids, enzymes, and bacteriocins that act as antimicrobial agents (Servin 2004). Lactobacillus, which comprises 175 listed species, is considered the most important LAB genus (Vasquéz et al. 2012); however, this genus is still under taxonomic discussion. The most prevalent Lactobacillus species was L. kunkeei, which is prevalent in many Apis species as reported by several researchers (Vasquéz et al. 2012; Tajabadi et al. 2011, 2013b).

Distinguishing phenotypic properties for the detection and identification of LAB in a microbiota increasingly relies on molecular-based identification methods. For instance, sequencing rDNA genes (Settanni et al. 2005; Yoshiyama and Kimura 2009; Snell-Castro et al. 2005; Tajabadi et al. 2011, 2012, 2013b), which plays crucial roles in LAB identification and phylogenetic analyses (Ludwig and Schleifer 1999), has been used to identify Lactobacillus species.

The Asian dwarf honey bee (Apis florea) is a wild species with a broad distribution $(7000 \mathrm{~km})$, ranging from Vietnam and southeastern China, to south of the Himalayas, the Plateau of Iran, and south of Oman (Hepburn et al. 2005). Three morphoclusters including (Backhed et al. 2005) South India and Sri Lanka, (Bourtzis and Miller 2003) Thailand and (Chung et al. 1989) Oman, and Pakistan and Iran have been reported by Ruttner (1988), who studied 18 samples of A. florea and characterized 20 characters using key components and a factor analysis (Hepburn et al. 2005). However, Tahmasebi et al. (2002) defined two morphoclusters in southeastern and southwestern Iran. It would not be surprising if the wide distribution of this species caused a significant difference in the microflora living in the guts of these insects from different regions. It has been reported that the dominant LAB in the honey stomach of bees is significantly changed by sampling from different flowers during the year (Olofsson and Vasquéz 2008). To date, there is no documented study focusing on Lactobacillus in the gastrointestinal tract of the Asian dwarf honey bee (A. florea). This study will focus on the detection and identification of lactobacilli in the gastrointestinal tract of $A$. florea collected from different regions of Iran.

\section{MATERIALS AND METHODS}

Worker A. florea from 14 different southern regions of Iran (Figure 1) (300 individuals; 100 from three hives in each region) were collected from March to April 2015. Vegetation of each region where they were collected are listed in Table III. The samples were maintained in sterile glass tubes containing $10 \mathrm{ml}$ normal saline (Tajabadi et al. 2011), which were labeled and submitted to the Animal Science Research Institute of Iran for further processing. Thirty samples from each colony (10 individuals from three hives in each region) were individually dissected on a petri dish, and the whole gastrointestinal tract was collected using aseptic excision techniques under laminar flow (Olofsson and Vasquéz 2008).

\subsection{Culture method and biochemical screening}

Ten percent $(w / v)$ of honey stomach solutions was prepared in normal saline. To isolate lactobacilli, the honey stomachs were pooled and cultured on MRS (de Man, Rogosa, and Sharpe) agar medium (Oxoid). The isolates were incubated for 3-4 days at $37^{\circ} \mathrm{C}$ (Tajabadi et al. 2011) under anaerobic conditions using anaerobic jars with Anaerocult A gas packs (Merck, Darmstadt, Germany). To acquire pure bacterial isolates, 100 colonies with different morphologies were collected and subcultured.

Gram staining and catalase activity assays were conducted as an initial screening for Lactobacillus. Gram-positive and catalase-negative bacilli were selected (Coeuret et al. 2003). The isolates were maintained as described by Olofsson and Vasquéz (2008).

\subsection{DNA extraction}

A DNA extraction protocol using a kit (QIAGENE) and a method modified from Ward et al. (1994) were used to extract DNA. Briefly, all isolated cells were harvested in a microcentrifuge tube, after centrifuging for $10 \mathrm{~min}$ at $5000 \mathrm{~g}$. Bacterial pellet was resuspended in $180 \mu \mathrm{L}$ enzymatic lysis 


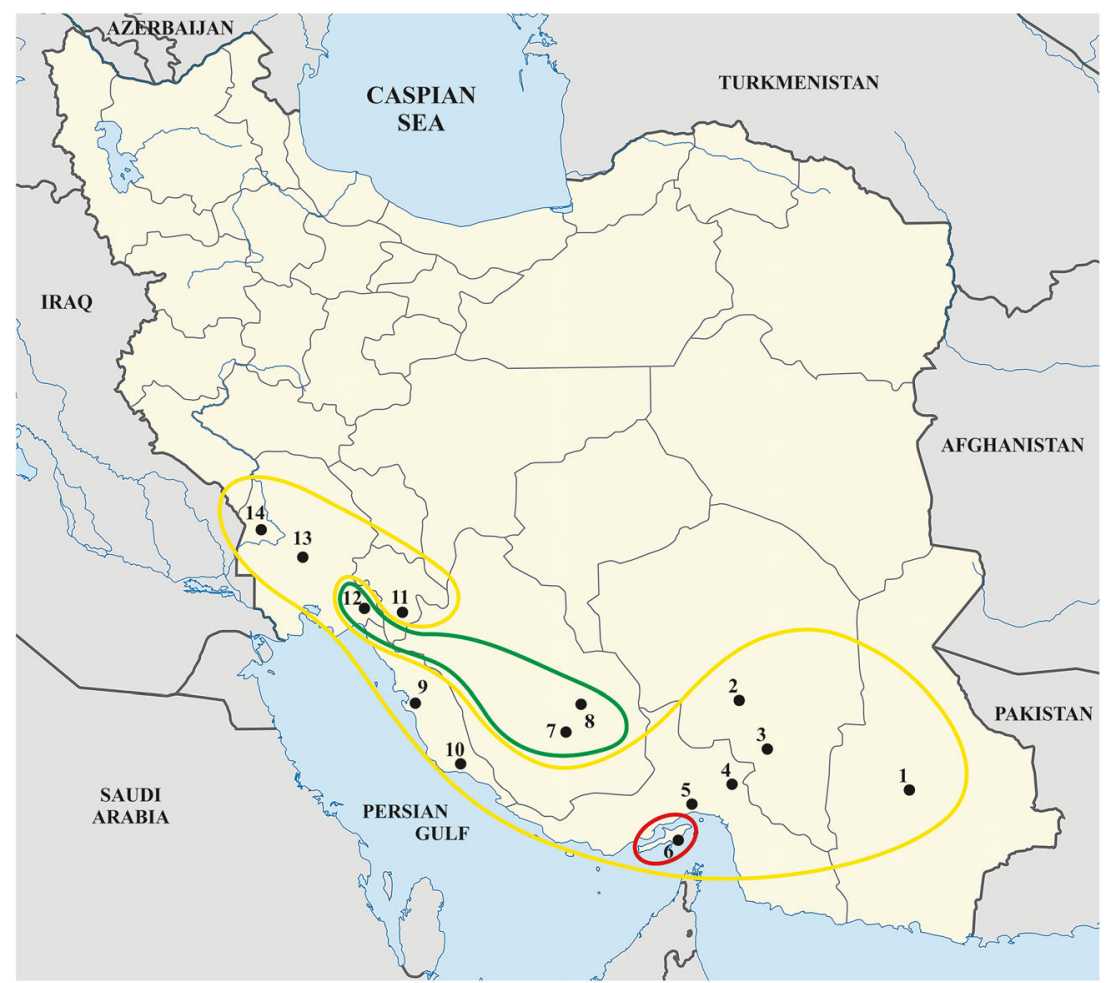

Figure 1. Collection sites of workers of the honey bee species, A. florea from different geographic regions of Iran (1 Iranshahr; 2 Jiroft; 3 Kahnuj; 4 Rudan; 5 Bandar Abas; 6 Qeshm; 7 Fasa; 8 Jahrom; 9 Bushehr; 10 Kangan; 11 Gachsaran; 12 Behbahan; 13 Ahvaz; 14 Dehloran) and distribution of Lactobacillus bacteria in these regions. Red region indicates Lactobacillus apis; yellow region, L. kunkeei ; and green region, L. plantarum.

buffer $(20 \mathrm{mM}$ Tris-Cl' $\mathrm{pH}=8.0$, Sigma-Aldrich, USA; 2 mM sodium salt of ethylenediaminetetraacetic acid (EDTA), Sigma-Aldrich, USA; $1.2 \%$ Triton X-100 solution, Sigma-Aldrich, USA; lysozyme $20 \mathrm{mg} / \mathrm{mL}$, QIAGene, Hilden, Germany) and incubated for at least $30 \mathrm{~min}$ at $37^{\circ} \mathrm{C}$. Twenty-five microliters of proteinase $\mathrm{K}$ and $200 \mu \mathrm{L}$ buffer $\mathrm{AL}$ (QIAGene, Hilden, Germany) were added into a tube and homogenized by vortexing and incubated at $56{ }^{\circ} \mathrm{C}$ for $30 \mathrm{~min}$. A volume of $200 \mu \mathrm{L}$ of ethanol (96\%) (HmBg Chemicals, Germany) was added to the sample and mixed thoroughly by vortexing. The sample was loaded into the DNeasy Mini spin column (QIAGene, Hilden, Germany) placed in a 2-mL collection tube and centrifuged at $6000 \mathrm{~g}$ for $1 \mathrm{~min}$. The DNeasy Mini spin column was transferred in a new 2-mL collection tube, $500 \mu \mathrm{L}$ buffer AW1 was added, and the resulting solution was centrifuged for 1 min at $6000 \mathrm{~g}$. Next, the DNeasy Mini spin column was placed in a new $2-\mathrm{mL}$ collection tube, $500 \mu \mathrm{L}$ of buffer AW2 (QIAGene, Hilden, Germany) was added, and the solution was again centrifuged for $3 \mathrm{~min}$ at $20,000 \mathrm{~g}$. Next, the DNeasy Mini spin column was placed in a clean 2-mL microcentrifuge tube, and $200 \mu \mathrm{L}$ of buffer AE was transferred directly to the DNeasy membrane. DNA samples were eluted in $150 \mu \mathrm{L}$ of double-distilled water and stored in a freezer at $-24{ }^{\circ} \mathrm{C}$. DNA quality was tested by running the samples on $1 \%$ agarose gel, and DNA purity was quantified using a spectrophotometer and recording the ratios of absorbance at 260 and $280 \mathrm{~nm}$.

\subsection{PCR and sequencing}

The 16S rDNA gene (1500 bp) was amplified using $27 \mathrm{~F}$ and $1492 \mathrm{R}$ primers (5'-AGAG TTTGATCCTGGCTCAG-3' and 5'-GGTT ACCTTGTTACGACTT-3', respectively), targeting lactobacilli at the genus level. Standard $\mathrm{PCR}$ reactions were conducted in a final reaction 
volume of $20 \mu \mathrm{L}$, which contained $0.1 \mu \mathrm{L}$ Pfu DNA polymerase, $2 \mu \mathrm{L}$ DNA polymerase buffer, $1.5 \mu \mathrm{L} \mathrm{MgSO}_{4}, 0.25 \mu \mathrm{L}$ forward and reverse primers, and $1 \mu \mathrm{L}$ DNA template. RNase-free water $(14.9 \mu \mathrm{L})$ was added to reach the final volume (Table I) (Tajabadi et al. 2013a).

PCR were conducted in the following conditions: initial DNA denaturation for $3 \mathrm{~min}$ at $95^{\circ} \mathrm{C}$ for 1 cycle, 40 cycles of $95^{\circ} \mathrm{C}$ for $30 \mathrm{~s}, 55^{\circ} \mathrm{C}$ for $30 \mathrm{~s}$, and $72{ }^{\circ} \mathrm{C}$ for $1 \mathrm{~min}$, and a final extension cycle of $72{ }^{\circ} \mathrm{C}$ for $10 \mathrm{~min}$ (Tajabadi et al. 2013a).

PCR products $(5 \mu \mathrm{L})$ were electrophoresed on $1 \%$ agarose gel and stained with ethidium bromide for visualization. PCR products were purified using a QIAquick PCR purification kit (QIAGEN, Hilden, Germany). The purified PCR products obtained from different isolates were sequenced using $27 \mathrm{~F}$ and 1492R primers by Sanger sequencing (Macrogen, South Korea). Sequences used in phylogenetic analyses were checked and aligned using DNAstar and ClustalX softwares. Sequences identified were compared directly with all 16S rDNA sequences registered in GenBank using BLASTN at the NCBI homepage (http://www.ncbi.nlm.nih.gov/BLAST/).

Phylogenetic analysis was conducted by a neighbor-joining method using the program Mega 4 (Tamura et al. 2007).

\subsection{Reference sequences used in the phylogenetic analysis}

The following bacterial 16S rDNA gene sequences were used in the phylogenetic analysis:

Table I. PCR ingredients, volumes, and concentration for each PCR tube.

\begin{tabular}{lcl}
\hline Component & Volume $(\mu \mathrm{L})$ & Standard \\
\hline Pfu DNA polymerase & 0.1 & $1 \times$ \\
DNA polymerase buffer & 2 & $10 \times$ \\
$\mathrm{MgSO}_{4}$ & 1.5 & $1.5 \mathrm{mM}$ \\
Forward primer & 0.25 & $0.25 \mathrm{mM}$ \\
Reverse primer & 0.25 & $0.25 \mathrm{mM}$ \\
DNA template & 1 & $0.4 \mathrm{ng}$ \\
Sterile distilled water & 14.9 & - \\
Total & 20.00 & - \\
\hline
\end{tabular}

L. kunkeei Mp2 contig 0016 (JPUI01000014) and L. kunkeei strain Mardan Taj-1 (GQ451613) (cluster I in Figure 2); L. plantarum WCFS1(NC004567) (cluster II in Figure 2); L. apis Hma11(KZKQ034001), L. alvei (AY667698), L. insectis (AY667699), L. helveticus IMAU50085 (FJ915631), and $L$. sp. Mardan Yazid-1 (GQ451614.1) (cluster III in Figure 2); L. parabuchneri YIT0272 (AB429372), L. kefiri YIT0222 (AB429371), L. buchneri (AB205055), and $L$. vermiforme (M59295) (cluster IV in Figure 2) (Tajabadi et al. 2011; Vasquez et al. 2009).

\section{RESULTS}

To perform limited biochemical tests, 100 colonies were selected from MRS plates. Forty-three colonies were sequenced and subjected to phylogenetic analysis. The isolated strains exhibited very high similarity (99\%) to the four closest database sequences deposited in NCBI (Table II). According to the phylogenetic analysis, eight different phenotypes belonging to three different species, L. kunkeei, L. plantarum, and L. apis, formed the Lactobacillus flora found in the gastrointestinal tract of $A$. florea. Five phenotypes were associated with L. kunkeei (cluster I in Figure 2 and Table II), and two phylotypes were associated with L. plantarum (cluster II in Figure 2 and Table II). Furthermore, L. apis formed cluster III, with a sequence similarity of 99\% compared with L. apis reported from A. mellifera (Figure 2 and Table II).

The results obtained revealed that L. kunkeei was associated with $A$. florea populations collected from 11 regions of Iran, such as Jiroft, Kahnouj, Kangan, Qeshm, Roudan, Bandar-Abbas, Bushehr, Ahwaz, Dehloran, Iranshahr, and Gachsaran, and L. plantarum was found in the gastrointestinal tracts of $A$. florea collected from Fassa, Jahrom, and Behbahan. Surprisingly, L. plantarum was isolated from bees sampled from citrus orchards. In addition, L. apis was isolated from bees collected from the Qeshm region (Figure 1, Table III). The nucleotide sequences of Lactobacillus 16S rDNA genes were deposited in the NCBI database under the accession numbers KU318418, KU359941, 


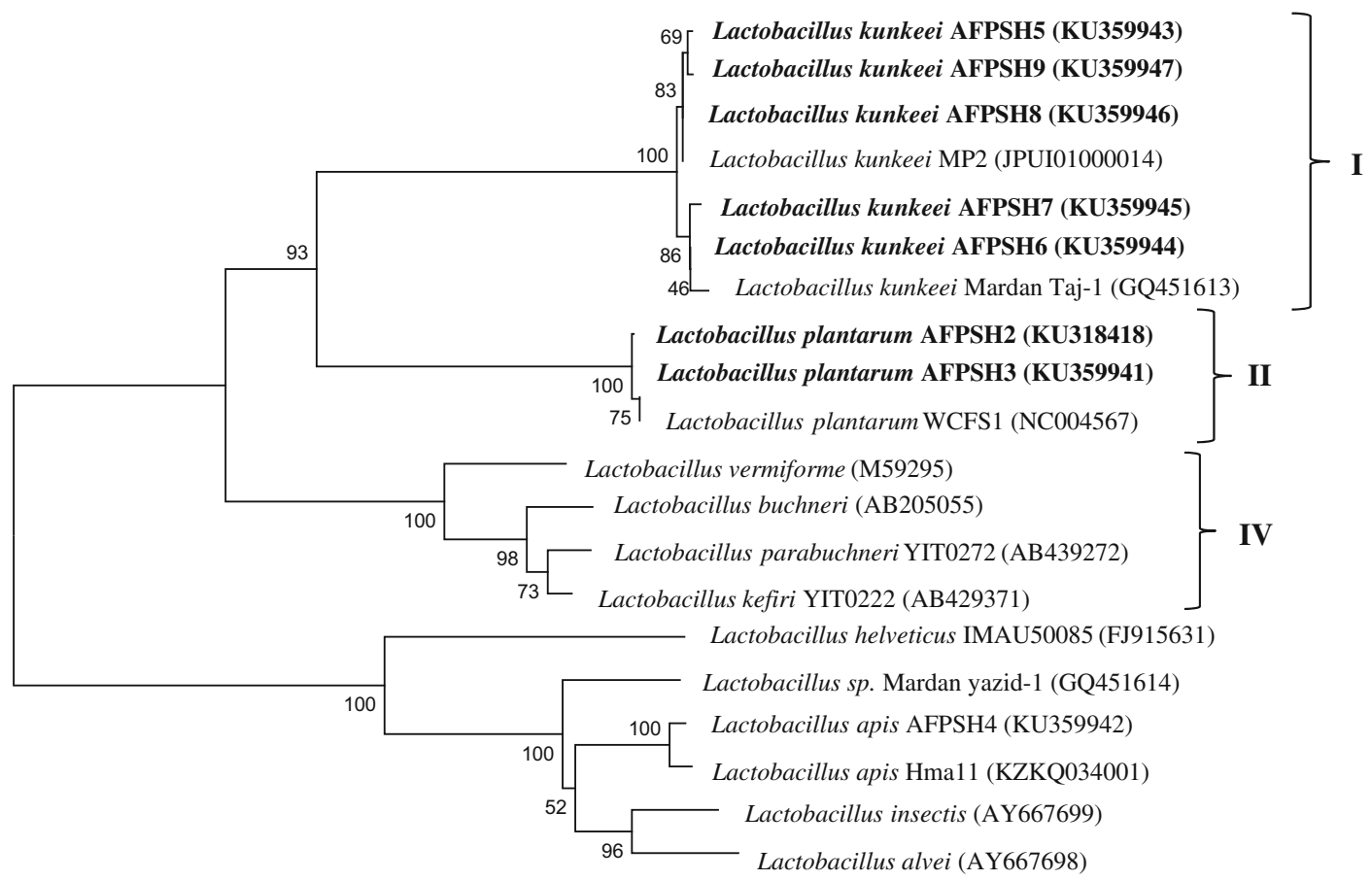

0.02

Figure 2. Phylogenetic analysis of Lactobacillus bacteria in honey bees collected from different regions of Iran (marked by bold face type). Phylogenetic tree based on a distance matrix analysis of 1275 positions in the 16S rDNA gene. The phylogenetic tree was constructed by ClustalW using the neighbor-joining method within the MEGA (4) package. Closely related type and reference strains are shown in parentheses together with accession numbers from GenBank. Bootstrap values based on 1000 resamplings display the significance of the interior nodes and are shown at branch points. Cluster I L. kunkeei group, cluster II L. plantarum group, cluster III L. apis group, and cluster IV as out group.

KU359942, KU59943, KU359944, KU359945, KU359946, and KU359947.

\section{DISCUSSION}

In most animals, intestinal microflora facilitates nutrient assimilation and immune function (Sandine 1979). Lactobacillus and Bifidobacterium are the most recognized LAB members housed in the gastrointestinal tract (Tajabadi et al. 2013b). Lactobacillus species are commercially important as they are used as probiotics in a wide range of food industries (Tajabadi et al. 2011). Traditionally, culturebased approaches were used to isolate and identify these numerous microorganisms (Gilliam 1979). Recently, culture-independent 16S rDNA gene sequence analyses have also been applied. In the current investigation, both classical cultivation procedures and $16 \mathrm{~S}$ rDNA sequencing were employed to identify bacterial diversity and the phylogenetic relationships of Lactobacillus housed in the gastrointestinal tract of A. florea.

The current phylogenetic analysis indicated that three different species of Lactobacillus associate with A. florea, which is distributed in different regions of southern Iran. Only three species of Lactobacillus were found to associate with A. florea, although all regions in which this species is distributed were sampled. Most of the populations harbored L. kunkeei, and three populations, including Jahrom, Fassa, and Behbahan, harbored L. plantarum. The population in Qeshm harbored L. apis and L. kunkeei. The populations 
Table II. Bacterial phylotypes originating from honey bee gastrointestinal tract of $A$. florea .

\begin{tabular}{|c|c|c|c|c|}
\hline Isolates $^{\mathrm{a}}$ & $\begin{array}{l}\text { Number of } \\
\text { identical }^{\mathrm{b}}\end{array}$ & Most closely related type strain ${ }^{c}$ & $\begin{array}{l}\text { Sequence lengths } \\
\text { and similarity }\end{array}$ & $\begin{array}{l}\text { Accession } \\
\text { numbers }\end{array}$ \\
\hline AFPSH2 & (4) & Lactobacillus plantarum WCFS1 & (1084) 99\% & KU318418 \\
\hline AFPSH3 & (7) & Lactobacillus plantarum WCFS1 & (1120 $99 \%$ & KU359941 \\
\hline AFPSH4 & (2) & Lactobacillus apis Hma11 & (896) $99 \%$ & KU359942 \\
\hline AFPSH5 & (4) & Lactobacillus kunkeei Mp2 contig 0016 & (1132) $98 \%$ & KU359943 \\
\hline AFPSH6 & $(8)$ & Lactobacillus kunkeei Mp2 contig 0016 & (1111) 99\% & KU359944 \\
\hline AFPSH7 & (5) & Lactobacillus kunkeei Mp2 contig 0016 & (1108) 99\% & KU359945 \\
\hline AFPSH8 & (7) & Lactobacillus kunkeei Mp2 contig 0016 & (1149) $97 \%$ & KU359946 \\
\hline AFPSH9 & (6) & Lactobacillus kunkeei Mp2 contig 0016 & (1113) 99\% & KU359947 \\
\hline
\end{tabular}

${ }^{\mathrm{a}}$ The identities of $16 \mathrm{~S}$ rDNA gene sequences were generated from isolates

${ }^{\mathrm{b}}$ The numbers of identical sequences found are shown in parentheses

${ }^{\mathrm{c}}$ GenBank accession numbers are shown in parentheses; taxonomic connection was established by comparing the sequence in the National Center for Biotechnology Information (NCBI)

${ }^{\mathrm{d}}$ The similarity to the closest type strain sequence is exhibited as a percentage inside parentheses

${ }^{\mathrm{e}}$ GenBank accession numbers for this study are shown in the last column

were classified into three zones: (1) Jiroft, Kahnouj, Roudan, Bandar-Abbas, Kangan, Bushehr, Qeshm, Ahwaz, Dehloran, Iranshahr, and Gachsaran; (2) Jahrom, Fassa, and Behbahan; and (3) Qeshm. Recently, Parichehreh et al. (2013) classified A. florea based on its morphological characteristics. One feature of their study is in agreement with the data presented here. They showed that the distribution of A. florea in Iran is composed of two populations: (1) Fars, Khuzestan, and Kohgiluyeh Boyer-Ahmad and (2) Bushehr, Sistan-Baluchestan, Hormozgan, and Kerman. Together with the findings of Parichehreh et al. (2013), the data presented here

Table III. Geographical distribution of Lactobacillus bacteria and vegetation in different regions of Iran.

\begin{tabular}{|c|c|c|c|c|c|}
\hline County & Province & Vegetation & L. plantarum & L. kunkeei & L. apis \\
\hline Jahrom & Fars & Citrus limon & + & & \\
\hline Fasa & Fars & Citrus limon & + & & \\
\hline Jiroft & Kerman & Phoenix dactylifera & & + & \\
\hline Kahnuj & Kerman & Prosopis cineraria & & + & \\
\hline Rudan & Bandar Abas & Phoenix dactylifera & & + & \\
\hline Bandar Abas & Bandar Abas & Prosopis cineraria & & + & \\
\hline Qeshm & Bandar Abas & Prosopis juliflora & & + & + \\
\hline Bushehr & Bushehr & Bougainvillea glabra & & + & \\
\hline Kangan & Bushehr & Bougainvillea glabra & & + & \\
\hline Gachsaran & Kohgiluyeh Boyer Ahmad & Eucalyptus camadulensis & & + & \\
\hline Ahvaz & Ahvaz & Conocarpus erectus & & + & \\
\hline Behbahan & Ahvaz & Citrus aurantium & + & & \\
\hline Dehloran & Ilam & Quercus persica & & + & \\
\hline Iranshahr & Sistan Baluchestan & Acacia sp. & & + & \\
\hline
\end{tabular}


move us towards a better understanding of the distribution of bacteria that interact with A. florea. Interestingly, bees collected from the Fars and Khuzestan populations in citrus orchards harbored L. plantarum. LAB diversity might be due to differences in the nutritional content of nectar and pollen or the microbes found on the flowers. Temporal differences in the microbes present on flowers may stimulate resident LAB microbiota growth in bees and activate antimicrobial substance production (Vasquéz et al. 2012). LAB strains are known to use this mechanism in other niches (e.g., L. reuteri when producing reuterin) (Chung et al. 1989; Talarico and Dobrogosz 1989). Gilliam (1979) found a consistent honey bee gastrointestinal tract microbiota, which was independent of season and geography, while Vasquéz et al. (2012) have reported that the type of LAB species living in the crop of bees depends on geographic differences in the distribution of the bees and could change depending on the season. However, they hypothesized that these differences result in changes in the honey crop microflora. Furthermore, they reported that foreign microbes can be easily introduced into the digestive tract of bees along with nectar through their honey stomach or into their colony via pollen transfer. Although pollen and nectar are sterile just before flowers open, they can become infected by airborne microorganisms or microbes carried by insects as soon as flowers open. The number and composition of transient microbes can change over time and are affected by flower species, insect species, air temperature, and nectar and pollen nutrient content. LAB members vary in terms of the numbers of each species present in the crop (Olofsson and Vasquéz 2008); however, they are constant within the same Apis species (Olofsson et al. 2011). Further works should be undertaken to address whether the Lactobacillus flora found in the gastrointestinal tract of A. florea change in relation to season.

A recent study conducted by Vasquéz et al. (2012) revealed that L. kunkeei is the most prevalent Lactobacillus species among Apis species (Vasquéz et al. 2012). Furthermore, this bacterium has been considered a wine-spoiling organism as it could have inhibitory effects on yeast growth in wine production (Edwards et al. 1998; Maarit
2004). Interestingly, they discovered that the degree of inhibition caused by single LAB members significantly differed when different microbial tests were used.

The next most prevalent lactobacilli found in the gastrointestinal tract of A. florea (AFPSH2 and AFPSH3) was L. plantarum. This species is normally considered as Generally Recognized as Safe (GRAS) by the US FDA, and many L. plantarum strains have been isolated from various ecological niches, such as fruits, cereal crops, vegetables, fish, fresh meat, and honey bees (A. dorsata) (Talarico and Dobrogosz 1989). Today, L. plantarum is widely applied in food processing methods, including use in fermentation as a starter culture and as an additive to improve food quality and sensory characteristics such as odor, texture, and consistency. Van Hoorde et al. (2008) have suggested that this species could be used for the protection of products because of the presence of lactic acid or additional antimicrobial agents.

The next most prevalent lactobacillus in the gastrointestinal tract of bees (AFPSH4) was L. apis. What is known about this species is mainly based on empirical studies conducted by Killer et al. (2014), who described how to isolate and identify this species as a novel member of the Lactobacillus genus. They found that this species has an inhibitory effect on Paenibacillus larvae (causal agent of American foulbrood (AFB) in honey bees) and Melissococcus plutonius (causal agent of European foulbrood (EFB)) growth under controlled conditions. A possible explanation for this is that Lactobacillus antimicrobial mechanisms establish a synergistic effect in honey bees to protect the bacteria and their hosts against external pressures, including microbes present in pollen or nectar and specific honey bee pathogens. This old symbiotic association between bees and LAB may provide an enormous advantage for bees (Kwong and Moran 2016). Lactobacillus species living in the digestive tract of honey bees, especially in the crop, have vital implications for pathologies in honey bees, especially for bacterial brood diseases like AFB or EFB. The results from a previous study carried out by Consortium (2006) showed that in comparison with other insects, honey bees harbor only $\sim 30 \%$ of the number of genes found in other insects that are 
involved in innate immunity mechanisms. In addition to the social defense observed in other social insects (Wilson-Rich et al. 2009), honey bees may also take advantage of LAB symbionts, which play a critical role in pathogen defense mechanisms to reduce their degree of dependency on the innate immune system.

Today, due to the overuse of antibiotics and the rise of resistant pathogens, researchers are looking for a new approach to control infectious diseases. Therefore, any effort to identify LAB can be considered as an important step towards industrial production of these bacteria to address infectious diseases in human and other animals. Identifying and applying these bacteria would help both honey bees and humans through our diet by producing probiotic honey or other products, and this topic deserves more investigation.

\section{AUTHOR CONTRIBUTIONS}

All the authors have read and approved the submitted manuscript.

Isolement et identification des bactéries Lactobacillus trouvées dans le tractus gastro-intestinal de l'abeille naine, Apis florea Fabricius, 1973 (Hymenoptera: Apidae)

\section{Apis florea / bactéries acide lactique / ADNr 16S / symbiose / Iran}

Isolierung und Identifizierung von Lactobacillus Bakterien aus dem Gastrointestinaltrakt der Zwerghonigbiene Apis florea Fabricius, 1973 (Hymenoptera : Apidae)

\section{Apis florea / Milchsäurebakterien / 16s rDNA / Symbi- ose / Iran}

\section{REFERENCES}

Backhed, F., J.L. Sonnenburg, DA. Peterson, JI. Gordon. 2005. Host bacterial mutualism in the human intestine. Science. 307:1915-1920.

Bourtzis, K., and TA. Miller. 2003. Insect Symbiosis. CRC Press, Boca Raton.

Chung, TC., L. Axelsson, SE. Lindgren, WJ, Dobrogosz. 1989. In vitro studies on reuterin synthesis by
Lactobacillus reuteri. Microb. Ecol. Health. Dis. 2: 137-144.

Coeuret, V., S. Dubernet, M. Bernardeau, M. Guegun, P. Vernouxj. 2003. Isolation, characterization and identification of lactobacilli focusing mainly on cheeses and other dairy products. Lait. 83:269-306.

Consortium, TS. 2006. Insights into social insects from the genome of the honey bee Apis mellifera. Nature. 443: 931-949.

Dillon, RJ., and VM. Dillon. 2004. The Gut Bacteria of Insects: Nonpathogenic Interactions. Annu. Rev. Entomol. 49:71-92.

Eckburg, PB., EM. Bik, CN. Bernstein, E. Purdom, L. Dethlefsen. 2005. Diversity of the human intestinal microbial flora. Science. 308:1635-1638.

Edwards, CG., KM. Haag, MD. Collins, RA. YC. Hutson Huang. 1998. Lactobacillus kunkeei sp. nov.: a spoilage organism associated with grape juice fermentations. J. Appl. Microb. 84: 698-702.

FAO/WHO. 2002. Guidelines for the Evaluation of Probiotics in Food: Joint FAO/WHO Working Group meeting. London Ontario, Canada. Available: http://www.who.int/foodsafety/publications/fs management/probiotics2/en/

Forsgren, E., TC. Olofsson, A. Vásquez, I. Fries. 2010. Novel lactic acid bacteria inhibiting Paenibacillus larvae in honey bee larvae. Apidologie. 41:99-108.

Gilliam, M. 1979. Microbiology of pollen and bee bread: the genus Bacillus . Apidologie. 10(3):269-274.

Hammes, W., C. Hertel. 2006. The Genera Lactobacillus and Carnobacterium. In The prokaryotes, pp. 320403. Springer US. https://doi.org/10.1007/0-38730744-3_10

Hepburn, R., E. Sarah, G. Radloff, LR. Fuchus, T. Chaiyawong, G. Tahmasbi, R. Ebadi. 2005. Apis florea : morphometrics, classification and biogeography. Apidologie. 36:359-376.

Killer, S., I. Dubna, and P. Sedla. 2014. Lactobacillus apis sp. nov., from the stomach of honeybees (Apis mellifera), having an in vitro inhibitory effect on the causative agents of American and European foulbrood. Int. J. Sys. Evol. Microbiol. 64:152-157.

Kwong, W. K., \& Moran, N. A. 2016. Gut microbial communities of social bees. Nature Reviews Microbiol., 14(6):374.

Ludwig, W., and K. Schleifer. 1999. Phylogeny of bacteria beyond the 16S rRNA standard. ASM News. 65:752757.

Maarit, M. 2004. Lactic acid bacteria in vegetable fermentations. Fodd Science and Technology, pp. 419-430. Marcel Dekker, New York.

Olofsson, T., and A. Vasquéz. 2008. Detection and identification of a novel lactic acid bacterial flora within the honey stomach of the honeybee Apis mellifera. Curr. Microbiol. 57:356-363.

Olofsson, TC., A. Vásquez, D. Sammataro, J. Macharia. 2011. A scientific note on the lactic acid bacterial flora within the honeybee subspecies; Apis mellifera 
(Buckfast), A. m. scutellata, and A. m. monticola. Apidologie. 42(6):696-699.

Parichehreh, SH., MB. Farshineh Adl, and M. Fallahzadeh. 2013. Study and comparison of morphological characteristics of dwarf honey bees, Apis florea F. (Hymenoptera, Apidae) in Iran. J. Entomol. Res. 5(4):315-330.

Ruttner, F. 1988. Biogeography and taxonomy of honey bees. Springer-Verlag, Berlin, 285 pp.

Sandine, WE. 1979. Role of Lactobacillus in the intestinal tract. J. Food. Prot. 42:259-262.

Servin, AL. 2004. Antagonistic activities of Lactobacilli and Bifidobacteria against microbial pathogens. FEMS Microbiol. Rev. 28: 405-440.

Settanni, L., D. Van Sinderen, J. Rossi, A. Corsetti. 2005. Rapid differentiation and in situ detection of 16 sourdough Lactobacillus species by multiplex PCR. Appl. Environ. Microbiol. 71:3049-3059.

Snell-Castro, R., J. Godon, JP. Delgenès, P. Dabert. 2005. Characterisation of the microbial diversity in a pig manure storage pit using small subunit rRNA sequence analysis FEMS Microbiol and Ecol. 52:229-242.

Tahmasebi, G, R. Ebadi, N. Tajabadi, M. Akhondi, S. Faraji. 2002. The effects of geographical and climatological conditions on the morphological variation and separation of Iranian small honeybee (Apis florea F.) populations. J. Sci. Tech. Agri. Nat. Res. 6 (2):169-175.

Tajabadi, N, M. Mardan, M. Shuhaimi, MA. Meimandipour, L. Nateghi. 2011. Detection and identification of Lactobacillus bacteria found in the honey stomach of the giant honeybee Apis dorsata. Apidologie. 42:642-649.

Tajabadi, N., M. Mardan, F. Feizbadi, L. Nateghi, B. Rasti, YA. Manap. 2012. Weissella sp. Taj-Apis, a novel lactic acid bacterium isolated from honey. J. Food. Agri. Environ. 10:263-267.

Tajabadi, N., M. Mardan, MY. Manap, S. Mustafa. 2013a. Molecular identification of Lactobacillus spp. isolated from the honey comb of the honey bee (Apis dorsata) by $16 \mathrm{~S}$ rRNA gene sequencing. J. Apic. Res. 52(5): 235-241.

Tajabadi, N., M. Mardan, N. Saari, S. Mustafa, R. Bahreini, MY. Manap. 2013b. Identification of Lactobacillus plantarum, Lactobacillus pentosus and Lactobacillus fermentum from honey stomach of honeybee. Brazil. J. Microbiol. 44(3):717-722.

Talarico, TL., and WJ. Dobrogosz. 1989. Chemical characterization of an antimicrobial substance produced by Lactobacillus reuteri. Antimicrob. Age. Chemo. 33: 674-679.

Tamura, K., J. Dudley, M. Nei, S. Kumar. 2007. MEGA (4): Molecular evolutionary genetics analysis (MEGA) software version 4.0. Mol. Biol. Evol. 24:1596-1599.

Van Hoorde, K., T. Verstraete, P. Vandamme, G. Huys. 2008. Diversity of lactic acid bacteria in two Flemish artisan raw milk Gouda-type cheeses. Food Microbiol. 25:929-935.

Vasquez, A., TC. Olofsson, and D. Sammataro. 2009. A scientific note on the lactic acid bacterial flora in honeybees in the USA - a comparison with bees from Sweden. Apidologie. 40, 26-28.

Vasquéz, A., E. Forsgren, I. Fries, R. Paxton, E. Flaberg, L. Szekely, T. Olofsson. 2012. Symbionts as Major Modulators of Insect Health: Lactic Acid Bacteria and Honeybees. PlosOne, 7(3):1-9.

Ventura, M., S. Flaherty, MJ. Claesson, F. Turroni, TR. Klaenhammer. 2009. Genome-scale analyses of health-promoting bacteria: probiogenomics. Nature Rev. Microbiol. 7: 61-71.

Ward, L. J., Brown, J. C., \& Davey, G. P. 1994. Application of the ligase chain reaction to the detection of nisinA and nisinZ genes in Lactococcus lactis ssp. lactis. FEMS Microbiol. letters, 117(1):29-33.

Wilson-Rich, N., M. Spivak, NH. Fefferman, PT. Starks. 2009. Genetic, Individual, and group facilitation of disease resistance in insect societies. Annu. Rev. Entomol. 54:405-423.

Yoshiyama, M., and K. Kimura. 2009. Bacteria in the gut of Japanese honeybee, Apis cerana japonica and their antagonistic effect against Paenibacillus larvae, the causal agent of American foulbrood. J. Invert. Pathol. 102:91-96. 